\title{
Teaching Physics by Using Google Education Teaching Methods to K12 Students to Increase Learning Outcome
}

\author{
Felixtian Teknowijoyo \\ Educational Technology \\ Universitas Sebelas Maret, Surakarta, Indonesia \\ felixtian.teknowijoyo@student.uns.ac.id
}

\begin{abstract}
The rapid development of technology forced education in many schools to change drastically. Classic lecture methods began to be abandoned by educators and turned to computer-based learning methods, one of which was Google Education. The purpose of this article is to find out whether Google Education can improve student learning outcomes on Physics subject for K-12 students in Indonesia. The method of writing this study is a literature review of relevant research journals. The problem faced by students in understanding the concept of a superficial lesson is caused by conventional teaching methods. By using Google Education-based learning students actively understood the concept of learning, which involves communication and collaboration among them, thereby increasing students' critical thinking skills and their learning outcomes.
\end{abstract}

Keywords: Media, Physics, Google, Google Education, Learning Outcomes, Middle School

\section{INTRODUCTION}

Physics study aims so that we can know the basic parts of objects and then understand the interactions between them, also include explanations of the natural phenomena that occur around us. Studying Physics in school becomes a challenge because students must combine unseen and indirect experience of natural concepts also the skills of calculations to solve mathematical equations[1][2][3].

Junior high school students are expected to master Physics competencies while studying in school. This is in line with the Indonesian national curriculum that helps students to think more logically and critically, to follow the latest technology, to understand global challenges that help them determine the direction of further education. But in reality, the achievements of junior high school students on the National Examination in Natural Sciences are still far from what was expected. Recorded in the Education Assessment Center data the average of science lessons at the junior secondary level in Indonesia in the 2018/2019 school year was 48.79 from 100 . This figure has increased by 0.74 from the previous school year but when compared 
to the previous years namely the $2016 / 2017$ school year, the number has decreased by 3.57 points [4].

On the other hand the teachers still often use the classic method and drilling questions in Physics lectures at school. Often teachers directly offer applied formulas to solve physics equations without making a strong foundation of physics concepts. Several alternatives have been studied and produced positive results, such as variations in learning models (cooperative learning, contextual learning, problem-based learning, etc.), including making research at the laboratory. But the preparation for this methods teachers need more time and energy, and often they do not have enough of these [5].

Insane get data that $77 \%$ of junior high school students who use the internet to add knowledge to master competencies are expected to get higher learning achievement than before in physics [11]. And at this time the progress of internet technology and its use in Indonesia is increasing. Statistical results from the Association of Indonesian Internet Network Providers stated that internet users in 2018 in Indonesia were 171.17 million from a total of 264.16 million people (64.8\%) and this figure had increased by around 10.12 percent from the previous year [6]. This has become an opportunity for the development of internet-based teaching materials to improve student learning outcomes in Physics.

Google Education has been developed by a giant company from America that emphasizes innovation and productivity of education. This web-based internet product aims to equip and encourage students to have knowledge and skills that are in line with the present and future education. This technology is considered as part of the solution to the problems that occur in education, namely helping students learn according to their respective styles, collaborating with others online, and being beings who have critical thinking in solving problems. The TAM or Technology Acceptance Model of the product shows that the majority of students successfully use it easily and quickly, resulting in a high level of satisfaction [7][8].

Therefore, with the development of learning media using Google-based education, it is hoped that students will have a more comfortable and effective learning experience in improving their learning outcomes.

\section{METHOD}

This study uses a method from literature review of relevant research journals. This method gathers and synthesizes previous studies and then by analyzing all of them a new perspective will be found that reinforces this study. Also after criticizing and evaluating this study allows for a new discovery at a meta level that opens up parts that have not been previously studied and support the product development [9].

\section{RESULT AND DISCUSSION}

\subsection{Physics Lessons in Junior High School}

By referring to the core and basic competencies that contained in national education standards each education unit (school) is given the freedom to develop an Education Unit Level Curriculum (KTSP) by making a syllabus and lesson plans in accordance with the vision, mission, and conditions of each school. In connection with learning physics at school, the development of physics curriculum becomes an obligation for every physics teacher at school concerned, thus the physics teacher is responsible for developing by making their own and authentic syllabus and lesson plans. In the syllabus and lesson plans in addition to basic competencies and competency standards, indicators, teaching materials, objectives, methods, 
sources of tools and materials must be explicitly included as well as evaluations. Here are some competencies in physics subject in accordance with the 2013 national curriculum along with the achievements of the average National Examination in 2019.

TABLE 1

SUMMARY OF THE AVERAGE NATIONAL EXAM SCORES

\begin{tabular}{|c|c|c|}
\hline $\begin{array}{l}\text { CORE COMPETENCY } 3 \\
\text { (KNOWLEDGE) }\end{array}$ & $\begin{array}{l}\text { CORE COMPETENCY } 4 \\
\text { (SKILLS) }\end{array}$ & \multirow{2}{*}{$\begin{array}{l}\text { Average } \\
\text { Achievement } \\
\text { of National } \\
\text { Exams* }\end{array}$} \\
\hline Basic & competencies Basic competency & \\
\hline $\begin{array}{l}\text { Applying the concept of measuring } \\
\text { various quantities by using standard units } \\
\text { (default). }\end{array}$ & $\begin{array}{l}\text { Present measurement data with } \\
\text { measurement tools that are suitable for } \\
\text { yourself, other living things, and objects } \\
\text { around by using non- } \\
\text { standard units and standard units. }\end{array}$ & 45 \\
\hline $\begin{array}{l}\text { Analyzing the solar system, the rotation } \\
\text { and revolution of the earth, the rotation } \\
\text { and revolution of the moon, and their } \\
\text { impact on life on earth. }\end{array}$ & $\begin{array}{l}\text { Presenting work on the effects of the } \\
\text { rotation and revolution of the earth and } \\
\text { the moon on life on earth, based on } \\
\text { observations or searches of various } \\
\text { sources of information. }\end{array}$ & 60 \\
\hline $\begin{array}{l}\text { Explain the pressure of substances and } \\
\text { their application in daily life, including } \\
\text { blood pressure, osmosis, and capillary } \\
\text { transport of tissues in plants. }\end{array}$ & $\begin{array}{l}\text { Present experimental data to investigate } \\
\text { the pressure of liquid at a certain depth, } \\
\text { buoyancy, and capillarity, for example in } \\
\text { plant stems. }\end{array}$ & 50 \\
\hline $\begin{array}{l}\text { Analyzing the concepts of vibrations, } \\
\text { waves and sounds in everyday life } \\
\text { including the human hearing system and } \\
\text { the sonar system in animals. }\end{array}$ & $\begin{array}{l}\text { Presenting the results of experiments } \\
\text { about vibration, waves, and sound. }\end{array}$ & 30 \\
\hline $\begin{array}{l}\text { Analyzing the properties of light, the } \\
\text { formation of shadows on flat and curved } \\
\text { fields and their application to explain the } \\
\text { process of human vision, insect eyes, and } \\
\text { the working principle of optical devices. }\end{array}$ & $\begin{array}{l}\text { Presenting the results of experiments on } \\
\text { the formation of shadows on mirrors and } \\
\text { lenses. }\end{array}$ & 30 \\
\hline
\end{tabular}

Above achievements are obtained from a summary of the average national exam scores that have been adjusted to their respective basic competencies.

\subsection{Google Education}

Google Education sees that both every student and educator needs certain teaching materials and competencies to get a successful learning, which leads to a desired dream in the 
future. Education that continues to evolve from time to time makes the challenges of education today more important than ever, namely how to support the learning of students preparing for the challenges and career paths they will face, which may not be available at this time [10][11]. By conducting various kinds of research Google Education has 8 important aspects to welcome the current educational trends: digital responsibility, life skills, computational thinking, student based learning, collaboration, role of parents or guardians, teacher's role, and incorporate new technology.

The digital world or cyberspace is now more widespread and free, while parents tend to give freedom to their children to use and explore cyberspace freely. Therefore many surveys say that school curricula must be regulated not only to provide science material but also how to teach students to understand risk and be responsible for exploring cyberspace. A holistic or educational needs become a necessity at this time, skills that are based on high emotional intelligence (EQ) become important values in the world of work, namely when one day students must be able to become leaders or be tough in the face of work pressure. This leads to increasing challenges in the future, an independence of students in learning becomes the key and focus of education. The role of educators is to help students love existing subject matter and create a learning environment (activities learning and teaching materials) that lead to student activeness. So an educator acts as an agent of change that helps motivate students with good and quality teaching materials [12].

Many studies say that the conditions of the learning space such as light intensity, color, acoustics, and placement of tables and chairs affect the learner's mood. Barett said the learning environment that $43 \%$ of successful learning experiences and achievements are supported by a supportive environment [13]. With Google Education opens up opportunities to provide students a convenient study environment with a real-time collaboration experience. Google Education makes it easy for educators to prepare teaching materials and evaluation results more quickly, including artificial intelligence technology, virtual reality, augmented reality are rapidly developing and adopted by schools to improve learning effectiveness. Google Education makes it possible to connect a variety of learning approaches using technology, however the technology will be meaningful only if it is planned in advance and implemented on appropriate subject matter.

Education will provide students with the basic skills and knowledge they will rely on for the rest of their lives. And as the world around them changes - in terms of culture, life values, shifts in community norms or technology as well as innovation will also change their responses to education. So education will be developed so that students are more connected with it in their lives, which is very clear will equip their future. By opening up space for innovation in learning by using technology, it will facilitate and enhance the abilities of both students and educators, which creates an efficient and effective learning ecosystem.

\subsection{Teaching Physics Materials Based on Google Education to Improve Student Learning Outcomes Teaching}

Materials that use Google Education are arranged systematically in electronic format. Development of teaching materials is made online using a web browser with an interesting and interactive. Following are some of the steps needed in making Physics teaching materials using Google Education [14]. 


\begin{tabular}{l|l|}
\hline \multicolumn{1}{|c|}{ Stages } \\
$\begin{array}{l}\text { Stage 1: Defining the } \\
\text { basic competencies. }\end{array}$ & $\begin{array}{l}\text { Master establishes and basic competences material to be taught. } \\
\text { And provide learning objectives in the clearly visible part. }\end{array}$ \\
\hline $\begin{array}{l}\text { Stage 2: Arrange material } \\
\text { in an interesting way }\end{array}$ & $\begin{array}{l}\text { The material is arranged in such a way as to form a mind map } \\
\text { that attracts the attention of students. (with Google Docs) }\end{array}$ \\
\hline $\begin{array}{l}\text { Stage 3: Gathering } \\
\text { supporting media }\end{array}$ & $\begin{array}{l}\text { Teachers look for videos or pictures that contain additional } \\
\text { information to provide enrichment of the material, so students } \\
\text { can view the material from various points of view. (with Google } \\
\text { Drawing, Youtube, etc.) }\end{array}$ \\
$\begin{array}{l}\text { Stage 4: Making group } \\
\text { assignments }\end{array}$ & $\begin{array}{l}\text { Physics Material becomes more challenging and interesting by } \\
\text { having group assignments that contain problem solving in } \\
\text { accordance with the material. (with Google Classroom, Google }\end{array}$ \\
$\begin{array}{l}\text { Docs) } \\
\text { Stage 5: Self-evaluation } \\
\text { Evaluation of }\end{array}$ & $\begin{array}{l}\text { Questions that refer to the material is made by considering the } \\
\text { difficulty of the problem. (with Google Form) }\end{array}$ \\
\hline $\begin{array}{l}\text { Stage 6: Presentation of } \\
\text { results }\end{array}$ & $\begin{array}{l}\text { Each group summarizes all material that has been obtained and } \\
\text { understood, then makes a paper or powerpoint. (with Google } \\
\text { Slide) }\end{array}$ \\
\hline $\begin{array}{l}\text { Teacher provides an assessment and comments on each student. } \\
\text { (with Google Classroom) [15]. }\end{array}$ \\
\hline
\end{tabular}

Based on the description above, it can be explained that the learning process by using Google Education teaching materials involves the role of students actively in solving problems given through assignments and exercises. Thus conventional physics learning will turn into interesting learning patterns and centered more on students. This learning model will train students to solve real problems with the intention to compile their own knowledge, practice critical thinking skills and the ability to solve problems. And this is evident from the increase in student learning outcomes[16] [17].

\section{CONCLUSION}

Based on the literature study above, it can be concluded that the need to create educational innovations through modern teaching materials is crucial. One of the learning materials that can support learning activities and actively involve the role of students in Physics is the media that uses Google Education. Some key principles of how necessary for effective learning include:students play an active role in their learning, they analyze a problem and actively create media messages to solve these problems. 
As teachers connect class activities with the world outside the classroom with technology, they actively monitors student work and development.Thenthey explicitly exposes students to learning experiences in the field of cyber-security and the use of appropriate technology.

So that these teaching materials make an easy independent learning for students. As these materials are presented clearly, contain questions that are designed to be meaningful and interesting, and can stimulate students in critical thinking, thereby increasing understanding of the material concepts and competencies that must be mastered by students, that make an impact for improving their learning outcomes.

\section{REFERENCES}

[1] R. Azizah, L. Yuliati, and E. Latifah, "The Physic Problem Solving Difficulties on High School Student," J. Penelit. Fis. dan Apl., vol. 5, no. 2, 2015.

[2] D. C. Giancoli, Physics: Principles with Applications, 3rd ed. Prentice Hall, 1991.

[3] A. N. Adriani, "Analisis Kesulitan Siswa Dalam Menyelesaikan Soal Fisika, dan Efektivitas Program Remidi Sebagai Upaya Membantu Siswa Kelas X di SMA Stella Duce Bantul untuk Memahami Materi Vektor," Sanata Dharma University, 2012.

[4] "Hasil laporan ujian nasional capaian wilayah \&amp; satuan pendidikan," Pusat Penelitian Pendidikan Kementrian Pendidikan dan Kebudayaan, 2019. [Online]. Available: https://puspendik.kemdikbud.go.id/hasil-un/. [Accessed: 26-Aug-2019].

[5] D. Rahono and W. Sunarno, "Pembelajaran Fisika dengan Pendekatan Problem Solving Melalui Metode Demonstrasi dan Eksperimen Untuk Meningkatkan Motivasi dan Hasil Belajar Siswa," 2014.

[6] "Survey of Indonesia Internet User Behavior Profile 2018," APJII, 2019. [Online]. Available: https://apjii.or.id/survei2018s. [Accessed: 08-Oct-2019].

[7] I. Nizal, M. Shaharanee, J. M. Jamil, S. Syamimi, and M. Rodzi, "The Application of Google Classroom as a Tool for Teaching and Learning," vol. 8, no. 10, pp. 1-8, 2016.

[8] Y. Ramma, A. Bholoa, M. Watts, and P. S. Nadal, "Teaching and learning physics using technology: Making a case for the affective domain," Educ. Inq., vol. 9, no. 2, pp. 210-236, Apr. 2018.

[9] H. Snyder, "Literature review as a research methodology: An overview and guidelines," J. Bus. Res., vol. 104, pp. 333-339, 2019.

[10] A. Otitodirichukwu, "Factors Affecting Students' Use of Google Apps For Education In Developing Countries (A Case Study of University of Benin Undergraduates)," Benin City, 2015.

[11] "Future of the Classroom Emerging Trends in K-12 Education Global Edition," 2019.

[12] "Solicita los informes de resultados," Blink Learning, 2018. [Online]. Available: https://www.realinfluencers.es/wp-content/uploads/2018/11/iv-estudio-tic-2018-espana.pdf. [Accessed: 06-Oct-2019].

[13] P. Barrett, F. Davies, Y. Zhang, and L. Barrett, "The impact of classroom design on pupils' learning: Final results of a holistic, multi-level analysis," Build. Environ., vol. 89, pp. 118-133, 2015.

[14] S. Widodo, "Implementing Google Apps for Education as Learning Management System in Math Education," J. Phys. Conf. Ser., vol. 895, pp. 12-53, Sep. 2017.

[15] "GOOGLE CLASSROOM: Guide for Students," ACT Governments: Education and Training, 2018. [Online]. Available: https://mail.google.com/a/schoolsnet.act.edu.au. [Accessed: 08-Oct2019].

[16] B. Host, "Does Using Technology in the Classroom Improve Student Outcomes?," 2019. [Online]. Available: https:/educationtechnologysolutions.com/2019/05/technology-classroomimprove-student-outcomes/. [Accessed: 10-Nov-2019].

[17] K. Saddhono, Suhartatik, Bagiya, Widodo, and H. Wahyono, "Learning vocabularies using multimedia-based Teaching Indonesian to Speakers of Other Languages (TISOL)," in Journal of 
Physics: Conference Series, 2019, p. 012108. 